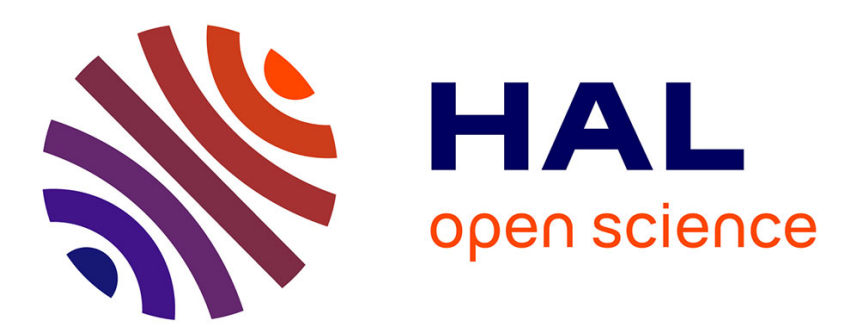

\title{
Origin differences in self-reported health among older migrants living in France
}

\author{
Nicolas Gérard Vaillant, François-Charles Wolff
}

\section{To cite this version:}

Nicolas Gérard Vaillant, François-Charles Wolff. Origin differences in self-reported health among older migrants living in France. 2010. hal-00449608

\section{HAL Id: hal-00449608 \\ https://hal.science/hal-00449608}

Preprint submitted on 22 Jan 2010

HAL is a multi-disciplinary open access archive for the deposit and dissemination of scientific research documents, whether they are published or not. The documents may come from teaching and research institutions in France or abroad, or from public or private research centers.
L'archive ouverte pluridisciplinaire HAL, est destinée au dépôt et à la diffusion de documents scientifiques de niveau recherche, publiés ou non, émanant des établissements d'enseignement et de recherche français ou étrangers, des laboratoires publics ou privés. 
EA 4272

\title{
Origin differences in self-reported health among older migrants living in France
}

\author{
Nicolas Vaillant * \\ François-Charles Wolff **
}

2010/01

* LEM - Université Catholique de Lille

${ }^{* *}$ LEMNA : Université de Nantes - CNAV et INED : Paris

Laboratoire d'Economie et de Management Nantes-Atlantique Université de Nantes 


\title{
Origin differences in self-reported health among older migrants living in France
}

\author{
Nicolas Vaillant * François-Charles Wolff ${ }^{* *}$
}

Janvier 2010

\begin{abstract}
Objectives: Little is known about the health status of older migrants living in Europe. Using detailed data collected in 2003, we investigate differences in health status by origin country within the older immigrant population living in France using a self-rated health measure.

Study design: The database used in this research is the 'Passage à la Retraite des Immigrés' survey, conducted from November 2002 to February 2003 on a sample of 6,211 migrants aged 45 to 70 and living in France at the time of survey.

Methods: A difficulty with the self-rated outcome is that it may not be comparable between different origin groups, in particular because of cultural and linguistic differences. We thus estimate generalized ordered Probit models and construct for each respondent an indicator of health net of cross-cultural effects.

Results: Male immigrants from Southern Africa and Asia and female immigrants from Northern Europe, Southern Africa and Asia are more likely to be in good health, while the health status is lower among immigrants from Eastern Europe living in France.

Conclusion: The diversity in health status within the immigrant population is large in France. These results are helpful in order to target the more disadvantaged origin groups and to adjust the provision of health care.
\end{abstract}

JEL Classification: I12, J15

Keywords: Self-assessed health, immigrants, origin differences, France

\footnotetext{
* LEM (UMR 8179 CNRS) and Université Catholique de Lille (FLSEG), 60 bd Vauban, BP109, 59016 Lille Cedex, France.

E-mail : nicolas.vaillant@icl-lille.fr http://ngvaillant.e-monsite.com/

** Corresponding author. Professor of Economics, University of Nantes. LEMNA, Université de Nantes, BP52231 Chemin de la Censive du Tertre, 44322 Nantes Cedex; CNAV and INED, Paris, France. Tel : 33240 141779 , Fax : 33240141700 .

E-mail: francois.wolff@univ-nantes.fr http://www.sc-eco.univ-nantes.fr/ fcwolff/
} 


\section{Introduction}

Knowing the health status of immigrants is particularly important to health policy planners, as it provides unique opportunities to improve health care. However, the link between migration and health is complex on a priori grounds.

According to the healthy migrant hypothesis ${ }^{1,2,3}$, the health status of immigrants at the time of arrival is usually better than that of the native-born population because of the positive selection of immigrants among their origin population. The migration decision will then affect the health of those who have migrated, the immigrant health status deteriorating with the duration of residence. At the same time, according to the salmon bias, many migrants return to their country of birth after retirement or becoming seriously ill, reflecting their desire to die in their own birth place ${ }^{4}$. This type of selective emigration results in lower mortality among the migrants who choose not to return to their country of birth ${ }^{5}$.

From an empirical perspective, numerous studies have focused on health disparities, both within the immigrant population and between immigrants and natives living in the United States ${ }^{6}$, a country being characterized by a rapid acceleration and diversification of immigrants over the last thirty years. The main conclusions are that foreign-born individuals are in better health than native-born Americans and that there is a significant heterogeneity in health among immigrants ${ }^{7}$. The populations under consideration are essentially made up of middle-aged adults, which is undoubtedly due to the fact that migration has primarily been associated with labor considerations. However, this perception is now contradicted by the aging of immigrants and the health of the older immigrants is of special interest since most changes in health occur during old age.

Like the US, European countries are characterized by a large number of immigrants and the proportion of immigrants in the ages of retirement is increasing. Despite the interest in studying the health status of immigrants, research on this issue remain scarce in Europe, 
recent exceptions being found in the Netherlands ${ }^{8}$, in Sweden ${ }^{9}$ and in France ${ }^{10,11}$. In that latter country, several studies have evidenced a heterogeneous relationship between immigration status and health after controlling for socio-economic status, depending on age at immigration, gender and origin ${ }^{12}$.

For instance, health benefits are noticeable among Mediterranean men, especially for affluence-related diseases such as cancer and cardiovascular diseases ${ }^{13}$. When being compared to local-born French and non-migrant Tunisians, migrants from Tunisia have lower mortality and morbidity rates when considering nutrition-related non-communicable diseases $^{14}$. An explanation is that their acculturation led to a convergence of some of their characteristics to those of the host population, while not others. Past and current exposure to the home country helped maintain some positive aspects of the diet ${ }^{15}$. Also, some unusual types of cancer (nasopharynx, bladder) are observed among migrants from Northern Africa, while these migrants have on average lower risks for most cancer sites ${ }^{16}$.

Clearly, there is a strong need for more research on aspects of migrant health in European countries ${ }^{17}$. Assessing the relevance of the healthy migrant or salmon hypotheses is undoubtedly of the highest importance, but detailed longitudinal data is usually required to understand the dynamics of health between the migrant and native populations. Instead of comparing the health status respectively of migrants and natives as done in previous studies, we choose in this paper to focus on differences in subjective health among the various origin groups of older immigrants living in France. A difficulty with a self-rated health measure is that it may not be comparable across cultural groups. In particular, some groups may give biased responses to the self-rated health indicator because of cultural and linguistic differences. We thus develop a simple methodology to adjust for these differences.

To study differences in health status within the immigrant population living in France, we use data collected in 2003 by the Caisse Nationale d'Assurance Vieillesse on a large 
sample of migrants aged 45 to 70 living in France. This survey provides detailed information on the characteristics of the respondents and includes a self-rated health measure, which is an accurate indicator of chronic disease and a good predictor of mortality ${ }^{18}$. We focus on differences in health by origin country and compare the health status of the different immigrant groups. Drawing on generalized Ordered Probit models with thresholds depending on both origin country and language proficiency, we compute health indicators net of crosscultural differences for each origin group. Our main result is that there remain large differences in self-rated health among the various origin groups living in France even after controlling for cultural differences.

The remainder of our paper is organized as follows. In the next Section, we describe the survey used and present our empirical strategy, which relies on generalized ordered Probit models. Econometric results are discussed in Section 3. Finally, Section 4 concludes.

\section{Methods}

To study origin differences among the immigrant population living in France, we use a cross-sectional dataset collected by the Caisse Nationale d'Assurance Vieillesse from November 2002 to February 2003. The 'Passage à la Retraite des Immigrés' survey (PRI) focuses on immigrants' experience of aging and retirement. It includes a large sample of migrants aged 45 to 70 living in France at the time of the survey ${ }^{19}$. Immigration is defined by place of birth (outside France) and nationality of birth (non-French). These criteria include individuals who have acquired French citizenship by naturalization, but they exclude French citizens (by birth) who were born in foreign countries.

The sample includes detailed information on exactly 6,211 respondents. Given the different country of birth of the respondents, we construct the following eight origin groups: Northern Europe $(\mathrm{N}=444)$, Southern Europe $(\mathrm{N}=2,322)$, Eastern Europe $(\mathrm{N}=269)$, Northern 
Africa $(\mathrm{N}=2,095)$, Southern Africa $(\mathrm{N}=379)$, America $(\mathrm{N}=125)$, Middle East $(\mathrm{N}=251)$ and Asia $(\mathrm{N}=326)$. Interestingly, $71 \%$ of the respondents come from three southern European countries (Italy, Portugal and Spain) and from three Northern African countries (Algeria, Morocco and Tunisia).

The PRI survey contains detailed information about the respondents' demographic and economic characteristics, including social network, migration history, work and retirement, health, support and intergenerational transfers, household income, savings and standards of living. To study differences in health among migrants, our dependent variable is a standard self-assessed measure given by the following question: 'at this moment, would you say that your health is: very good - good - fair - poor - very poor?'. Given the low number of respondents reporting a very poor health status $(\mathrm{N}=184)$, we choose to merge into one category the 'very poor' and 'poor' outcomes. We then define an ordered variable ranging from 1 when health is either 'very poor' or 'poor' to 4 when health is 'very good'.

We turn to an econometric analysis to estimate the role of individual characteristics and of origin country on the self-reported measure of subjective health. We assume there exists a latent, unobserved variable denoted by $H^{*}$ that provides a measure of the migrant's 'true' health, i.e., net of cultural effects. The health outcome $H^{*}$ is expressed as:

$$
H^{*}=X \beta+\varepsilon
$$

where $X$ is a set of covariates explaining health, $\beta$ is a vector of coefficients to estimate, and $\varepsilon$ is a random error term. By definition, $H^{*}$ remains unobserved, but the data provide instead some information on the self-reported health status $H$ ranging from 1 ('very poor' or 'poor' health) to 4 ('very good' health). We suppose that:

$$
H=j \quad \text { if } \quad \mu_{j-1} \leq H^{*}<\mu_{j}
$$


with $j=1, \ldots, 4$. The different parameters $\mu_{j}$ (with $\mu_{j-1}<\mu_{j}$ ) are threshold levels that have to be estimated jointly with the parameters, with $\mu_{0}=-\infty$ and $\mu_{4}=+\infty$. Assuming that the error term $\varepsilon$ is normally distributed, the corresponding specification is an ordered Probit model.

A shortcoming of this kind of ordered model is that it assumes fixed threshold values for the whole population under consideration. Unfortunately, previous studies have suggested that these threshold levels were unlikely to remain constant when comparing the self-assessed measure of health among different populations ${ }^{20}$. In order to relax this restrictive assumption of parallel lines, we assume that the different thresholds vary over the observations as a function of variables related to origin effects. In our context, both origin and language proficiency are expected to have a strong influence on the thresholds. This defines a generalized ordered Probit model ${ }^{21,22}$.

As we are interested in a comparison of health among the various origin groups (net of cultural effects), we use the generalized ordered estimates to compute the following predicted health outcome for each respondent $i$ :

$$
\hat{H}_{i}^{\text {origin }}=X_{i}^{\text {origin }} \beta
$$

To get normalized values for the health outcome, we calculate for the various origin groups $\hat{H}_{\min }^{\text {origin }}=\min \left(\hat{H}_{i}^{\text {origin }}\right)$ and $\hat{H}_{\max }^{\text {origin }}=\max \left(\hat{H}_{i}^{\text {origin }}\right)$. Then, for each respondent, we calculate a normalized indicator of health ranging from 0 to 1 and denoted by $\widetilde{H}_{i}^{\text {origin }}$ using:

$$
\widetilde{H}_{i}^{\text {origin }}=\frac{\hat{H}_{i}^{\text {origin }}-\hat{H}_{\min }^{\text {origin }}}{\hat{H}_{\max }^{\text {origin }}-\hat{H}_{\min }^{\text {origin }}}
$$

In so doing, we get comparable indicators of self-assessed health for the eight origin countries. For the comparison, we calculate the mean and the different percentile values along the health distribution. They indicate differences in health among the migrant population adjusted for the cross-cultural bias stemming from origin country and language proficiency. 
Let us finally describe the explanatory variables that we control for when estimating the generalized ordered model. First, we include a set of demographic controls related to gender, age, and marital status. Secondly, we take the socio-economic status of the respondent into account through the inclusion of education, occupational status during activity, quartiles of income measured at the household level, and whether the household is liquidityconstrained or not. Thirdly, we include more objective health indicators, as a separate source of information is needed to correct for presupposed differences in reporting.

On the one hand, the survey indicates whether the respondent has limitations with activities of daily living and instrumental activities of daily living. For the seven activities recorded in the survey (taking transportation, doing shopping, going outside, moving in the housing, doing housework, bathing/showering, preparing a meal), we construct a set of dummy variables being equal to 1 when the respondent reports a specific limitation (and 0 otherwise). We then sum up these dummies to get the total number of limitations with ADLs and IADLs. On the other hand, we include a dummy variable that takes the value of one when the respondent has spent at least one night in a hospital during the last twelve months. This covariate is strongly correlated with objective health problems ${ }^{23}$.

The fourth set of variables deals with parental characteristics. We introduce four dummy variables indicating whether the father and the mother of the respondent are alive or not at the date of the survey and whether, if alive, they are in poor health. Having parents alive and healthy should result in a positive correlation of high self-rated health status. Also, we know whether the financial situation of the respondent was very poor, poor, fair or good during youth, which may be seen as a good proxy of the parental socio-economic status.

Finally, the last set of covariates is about the migration trajectory itself. In the basic ordered Probit model, duration of migration, difficulty in reading French and origin country 
were included in the list of covariates. We only account for language proficiency and origin countries in the threshold equations when estimating the generalized ordered model.

\section{Results}

The distribution of the self-reported health outcome both for the whole population and for the various origin groups is described in Table 1. On average, the proportion of respondents in poor health amounts to $12.5 \%$. It is equal to $35.2 \%$ when the health status is fair, $38.9 \%$ when it is good, and $13.5 \%$ when it is very good. A crucial result of the PRI survey is that there are large differences in the self-reported health status among the various origin groups.

\section{Insert Table 1 here}

As shown in Table 1, 29.3\% of immigrants from Northern Europe feel themselves in very good health, while the same proportion is $10.3 \%$ among Southern Europeans. On the bottom of the health scale (very poor/poor health), immigrants from Southern Europe (14.1\%), from Northern Africa (14.6\%) and from Middle East (15.5\%) are above the average proportion of respondents in poor health $(12.5 \%)$. Conversely, the proportion of healthy respondents is higher than the average when immigrants originate from Northern Europe, Eastern Europe, America and Asia. The proportion of respondents self-reporting in either good or very good health is about $80 \%$ for Northern Europeans and $70 \%$ for Americans (while the average rate is $52.4 \%$ ).

Table 1 also suggests the existence of large differences in health among respondents from the same continent. On the one hand, immigrants from Southern Europe are more likely to have poor health status than immigrants from Northern Europe; the situation of Eastern Europeans is intermediate. On the other hand, with respect to Northern Africans, Southern Africans more often claim that they are either in good health (respectively $47.5 \%$ instead of 
$32.9 \%)$ or in very good health $(17.4 \%$ instead of $11 \%)$. These differences by origin country are very similar when considering separately men and women (Figure 1).

\section{Insert Figures 1 here}

As expected, men indicate more often than women that they are in either good or very good health $(55.8 \%$ instead of $48.3 \%)$. The three origin groups characterized by the highest proportion of respondents in poor health are Southern Europe, Northern Africa and Middle East both among men and women. The situation is slightly different among immigrants in very good health. Among men, healthy respondents are more frequently observed when originating from Northern Europe (33.5\%), America (34.8\%) and to a lesser extent from Southern Africa (22.2\%) and Asia (19.8\%). These groups are respectively Northern Europe (26.6\%), America (25.3\%), Asia (18.8\%) and Eastern Europe (15.5\%) among women.

Of course, differences in self-reported health observed among the various origin groups may simply be due to differences in individual characteristics. Descriptive statistics reported in Table 1 clearly show that there are large and significant differences in the characteristics of the respondents depending on their origin country.

Northern European immigrants are more often women and are slightly older. A higher education level and a higher socioeconomic status characterize them, while they are less likely to have objective health problems. They also have shorter duration of migration and face less difficulty in the host language proficiency. Immigrants from Southern European countries are older than the average respondent. More than one half of them have completed primary education only, they are more often workers or employees, and they have spent more years in France than the other immigrants. Respondents from Southern Africa are much younger and more educated on average than Northern Africans. Among the other groups, the main findings are the similarity between the Northern European and American groups, and the high proportions of men and low educated migrants in the Middle East group. 
Results from the generalized ordered Probit specification are described in Table 2. We estimate separate regressions for men and women since male and female migrants have different health profiles according to the data. We test the relevance of this assumption by adding a set of crossed gender-specific variables in a pooled regression (including both men and women). We find a value of 87.8 for the corresponding Chi2 statistic (with 38 degrees of freedom), statistically significant at the 1 percent level.

\section{Insert Table 2 here}

Let us briefly focus on the role of individual demographic and socio-economic characteristics. Table 2 indicates a negative relationship between self-reported health and the respondent's age, with a strong decreasing age profile among women only. While living as a couple does not affect the health outcome, the various socio-economic indicators have a positive influence in the ordered regression. First, the self-reported measure is positively correlated with the level of education of the immigrant among women, only the highest education category being significant among women. Secondly, those who are self-employed or executives report on average a better health. Thirdly, self-rated health is better on average when men and women are in the upper part of the household income distribution (third and fourth quartiles).

It is definitely not surprising to evidence a negative relationship between the self-rated measure of health and the two indicators of poor health conditions, both for men and women. Having any ADLs or IADLs or having spent at least one night in a hospital during the last twelve months strongly reduces the health outcome. Furthermore, the self-rated measure of health is better when the parents of the respondent are alive (especially among women) and not in poor health (especially among men). Being healthy is also more frequently observed among immigrants whose parents were either in a fair or in a good financial situation during youth, the reference category being a very poor situation. 
As shown in Table 2, many country effects have a significant and negative impact when considering the two upper thresholds, respectively from fair to good health and from good to very good health. In particular the health status is less favorable among immigrants from Southern Europe and from Northern Africa. Conversely, in the bottom of the health distribution, estimates from the generalized ordered regression indicate that with respect to Northern Europeans, only immigrants originating from Middle among men and from Southern Europe and Eastern Europe among women are more likely to be in poor health. Another result is that respondents having problems in reading French are less likely to be in the intermediate health status, both for men and women.

Using the generalized ordered estimates, we then compute the normalized indicator of health $\widetilde{H}_{i}^{\text {origin }}$ for each origin group. We present in Figure 2 respectively the mean value and the $25^{\text {th }}, 50^{\text {th }}$ and $75^{\text {th }}$ percentile values of $\widetilde{H}_{i}^{\text {origin }}$ for men and women. This provides a ranking in terms of health of the various origin groups, net of cross-cultural effects. When considering the whole sample, we get a mean health value of 0.760 among men and 0.736 among women. Among men, the highest mean values are found among immigrants from Asia (0.786), Southern Africa (0.759) and Southern Europe (0.750). The better origins in term of health among women are Northern Europe (0.787), Southern Africa (0.776) and Asia (0.756).

\section{Insert Figure 2 here}

The relative position (at the $1^{\text {st }}$ rank among men and the $3^{\text {rd }}$ among women) of Asian immigrants is interesting. On the basis of more objective individual characteristic, the objective health status of immigrants from Asia is better than what was suggested by their self-reported answers. An explanation could be that self-reported health most often encompasses physical, emotional and spiritual health among Asians ${ }^{24}$. On the bottom of the health scale, male immigrants from America (0.672) and Eastern Europe (0.721) and female 
immigrants from Eastern Europe (0.640) and Northern Africa (0.698) the worst health status (0.731). A few additional results are observed from the percentile values.

First, the worst health situations are really observed among female respondents from Eastern Europe, this group being characterized by the lowest $25^{\text {th }}$ percentile value. Secondly, there is more dispersion in health when immigrants come from Eastern Europe, America and Middle East. Conversely, there is less statistical dispersion among immigrants from Northern Europe, Southern Europe and Northern Africa. Finally, in the upper part of the health distribution, the highest third quartile value is found among respondents from Asia (0.870) and Middle East (0.849) among men, and from Southern Africa (0.878) and Northern Europe $(0.854)$

\section{Discussion}

Multi-ethnic societies in Europe are faced with multiple challenges, including the health needs of their different origin groups. In a context of population aging, there is very surprisingly little evidence to date on the health status among immigrant populations living in the European countries, whilst there are numerous studies on immigrant health in the United States. In this paper, we have attempted to fill in this gap by providing evidence on self-rated health among elderly immigrants living in France using detailed data collected in 2003. Instead of comparing immigrants and natives, we choose to focus on disparities in health status among different origin groups.

A difficulty with the self-rated health outcome is that this subjective measure may not be comparable across different ethnic groups, in particular because of cultural and linguistic differences. To overcome this difficulty, we have estimated generalized ordered Probit estimates with language proficiency and origin country as threshold-varying covariates. This allows us to construct for each immigrant an indicator of health net of cross-cultural effects. 
With respect to our methodology, we would like to point out that the crucial issue is to have accurate indicators of the objective health status of the migrants to really be able to isolate the cultural differences. Otherwise, the computation of the health index would also pick up differences in chronic diseases or in specific health troubles like problems with heart, diabetes, arthrosis, etc.

The comparison of the self-reported health measure will be more relevant with detailed information on objective health. The PRI survey is helpful with respect to this constraint since we were able to introduce more objective indicators such as limitations with activities of daily living or any hospital stay as well as parental characteristics (parents in poor health and alive). At the same time, a shortcoming of our approach concerns the limited number of variables related to origin effects, i.e., birth country dummies and language proficiency. The different thresholds could also be a function of variables related to the characteristics of the migrant's family.

We find that the diversity in health status within the immigrant population is large in France. Even after controlling for differences in socio-economic status and also for different perceptions of health depending on language proficiency and origin country, we still evidence significant differences in the health status of the different immigrant groups. On average, male immigrants from Asia and Southern Africa and female immigrants from Northern Europe, Southern Europe and Asia are more likely to be in good health, while the health status is lower among immigrants from Eastern Europe.

Because of the diversity of immigrants, our contribution shows that there is an appreciable difference when comparison is made by origin country. Interestingly, similar results were found for older immigrants living in the United States. As they stand, these results have important health-policy implications as they may be helpful in order to target the more disadvantaged origin groups and to adjust the provision of health care. For instance, one 
could propose free doctor consultations to both male and female migrants from Eastern Europe, since they are on average characterized by lower self-reported health (after controlling for cultural differences). Nevertheless, for that purpose, we believe that it would be worthwhile to have more information on the use of public services among the different immigrant groups. There is clearly a need for collecting more detailed data on health among the various ethnic groups living in European countries.

\section{Acknowledgements}

We are indebted to two anonymous referees for their very helpful comments on a previous draft. We also would like to thank Véronique Flambard and participants at the 26èmes Journées de Microéconomie Appliquée (Dijon) for their suggestions. The usual disclaimer applies.

\section{Ethical approval}

Ethical approval was unnecessary for this study.

\section{Funding}

Caisse Nationale d'Assurance Vieillesse

\section{Competing interests}

None declared 
Table 1. Descriptive statistics of the sample, by origin country

\begin{tabular}{|c|c|c|c|c|c|c|c|c|c|c|}
\hline \multicolumn{2}{|l|}{ Variables } & $\begin{array}{l}\text { Northern } \\
\text { Europe }\end{array}$ & $\begin{array}{c}\text { Southern } \\
\text { Europe }\end{array}$ & $\begin{array}{l}\text { Eastern } \\
\text { Europe }\end{array}$ & $\begin{array}{l}\text { Northern } \\
\text { Africa }\end{array}$ & $\begin{array}{c}\text { Southern } \\
\text { Africa }\end{array}$ & America & $\begin{array}{c}\text { Middle } \\
\text { East }\end{array}$ & Asia & All \\
\hline \multicolumn{11}{|c|}{ Dependent variable } \\
\hline Self-rated & Very poor/poor & 0.041 & 0.141 & 0.112 & 0.146 & 0.074 & 0.048 & 0.155 & 0.058 & 0.125 \\
\hline \multirow[t]{3}{*}{ health } & Fair & 0.158 & 0.364 & 0.242 & 0.415 & 0.277 & 0.248 & 0.367 & 0.337 & 0.352 \\
\hline & Good & 0.509 & 0.392 & 0.506 & 0.329 & 0.475 & 0.416 & 0.335 & 0.411 & 0.389 \\
\hline & Very good & 0.293 & 0.103 & 0.141 & 0.11 & 0.174 & 0.288 & 0.143 & 0.193 & 0.135 \\
\hline \multicolumn{11}{|c|}{ Explanatory variables } \\
\hline \multirow[t]{2}{*}{ Gender } & Male & 0.390 & 0.518 & 0.401 & 0.594 & 0.607 & 0.368 & 0.586 & 0.543 & 0.536 \\
\hline & Female & 0.610 & 0.482 & 0.599 & 0.406 & 0.393 & 0.632 & 0.414 & 0.457 & 0.464 \\
\hline \multirow[t]{5}{*}{ Age } & $45-49$ & 0.212 & 0.193 & 0.178 & 0.243 & 0.409 & 0.376 & 0.279 & 0.344 & 0.239 \\
\hline & $50-54$ & 0.182 & 0.224 & 0.245 & 0.247 & 0.235 & 0.248 & 0.378 & 0.288 & 0.241 \\
\hline & $55-59$ & 0.243 & 0.218 & 0.204 & 0.207 & 0.174 & 0.192 & 0.187 & 0.135 & 0.207 \\
\hline & $60-64$ & 0.191 & 0.163 & 0.175 & 0.164 & 0.121 & 0.088 & 0.100 & 0.117 & 0.157 \\
\hline & 65 and more & 0.171 & 0.202 & 0.197 & 0.139 & 0.061 & 0.096 & 0.056 & 0.117 & 0.157 \\
\hline \multirow[t]{2}{*}{ In couple } & No & 0.223 & 0.155 & 0.227 & 0.171 & 0.214 & 0.256 & 0.131 & 0.184 & 0.175 \\
\hline & Yes & 0.777 & 0.845 & 0.773 & 0.829 & 0.786 & 0.744 & 0.869 & 0.816 & 0.825 \\
\hline \multirow[t]{5}{*}{ Education } & Primary & 0.088 & 0.591 & 0.245 & 0.661 & 0.343 & 0.136 & 0.506 & 0.233 & 0.517 \\
\hline & ВEPC & 0.088 & 0.168 & 0.119 & 0.135 & 0.129 & 0.064 & 0.127 & 0.156 & 0.142 \\
\hline & BEP-CAP & 0.158 & 0.142 & 0.197 & 0.092 & 0.079 & 0.040 & 0.080 & 0.058 & 0.116 \\
\hline & Baccalaureate & 0.164 & 0.049 & 0.123 & 0.052 & 0.140 & 0.144 & 0.060 & 0.206 & 0.078 \\
\hline & High education & 0.502 & 0.050 & 0.316 & 0.061 & 0.309 & 0.616 & 0.227 & 0.347 & 0.148 \\
\hline \multirow[t]{6}{*}{ Occupation } & Self-employed & 0.092 & 0.077 & 0.045 & 0.057 & 0.047 & 0.008 & 0.112 & 0.077 & 0.068 \\
\hline & Executive & 0.300 & 0.058 & 0.123 & 0.036 & 0.129 & 0.272 & 0.084 & 0.163 & 0.086 \\
\hline & Intermediary & 0.218 & 0.113 & 0.152 & 0.070 & 0.124 & 0.208 & 0.064 & 0.107 & 0.108 \\
\hline & Employee & 0.234 & 0.267 & 0.260 & 0.179 & 0.306 & 0.288 & 0.104 & 0.270 & 0.231 \\
\hline & Worker & 0.097 & 0.436 & 0.394 & 0.478 & 0.354 & 0.168 & 0.454 & 0.331 & 0.409 \\
\hline & Inactive & 0.059 & 0.050 & 0.026 & 0.181 & 0.040 & 0.056 & 0.183 & 0.052 & 0.099 \\
\hline \multirow{4}{*}{$\begin{array}{l}\text { Household } \\
\ldots \text { income }\end{array}$} & Quartile 1 & 0.128 & 0.212 & 0.204 & 0.331 & 0.248 & 0.176 & 0.271 & 0.215 & 0.250 \\
\hline & Quartile 2 & 0.162 & 0.245 & 0.260 & 0.287 & 0.237 & 0.176 & 0.267 & 0.187 & 0.250 \\
\hline & Quartile 3 & 0.214 & 0.291 & 0.216 & 0.222 & 0.232 & 0.224 & 0.227 & 0.261 & 0.250 \\
\hline & Quartile 4 & 0.495 & 0.252 & 0.320 & 0.159 & 0.282 & 0.424 & 0.235 & 0.337 & 0.250 \\
\hline \multirow{4}{*}{$\begin{array}{l}\text { Liquidity } \\
\text {... constrained } \\
\text { Any IADL }\end{array}$} & No & 0.941 & 0.913 & 0.918 & 0.736 & 0.689 & 0.848 & 0.769 & 0.853 & 0.831 \\
\hline & Yes & 0.059 & 0.087 & 0.082 & 0.264 & 0.311 & 0.152 & 0.231 & 0.147 & 0.169 \\
\hline & No & 0.950 & 0.861 & 0.907 & 0.842 & 0.905 & 0.968 & 0.829 & 0.951 & 0.871 \\
\hline & Yes & 0.050 & 0.139 & 0.093 & 0.158 & 0.095 & 0.032 & 0.171 & 0.049 & 0.129 \\
\hline \multirow{2}{*}{$\begin{array}{l}\text { Any stay in } \\
\ldots \text { hospital }\end{array}$} & No & 0.887 & 0.845 & 0.851 & 0.810 & 0.863 & 0.864 & 0.880 & 0.911 & 0.843 \\
\hline & Yes & 0.113 & 0.155 & 0.149 & 0.190 & 0.137 & 0.136 & 0.120 & 0.089 & 0.157 \\
\hline \multirow{2}{*}{$\begin{array}{l}\text { Difficulty in } \\
\ldots \text { reading }\end{array}$} & No & 0.840 & 0.632 & 0.651 & 0.499 & 0.712 & 0.856 & 0.371 & 0.525 & 0.596 \\
\hline & Yes & 0.160 & 0.368 & 0.349 & 0.501 & 0.288 & 0.144 & 0.629 & 0.475 & 0.404 \\
\hline \multirow{4}{*}{$\begin{array}{l}\text { Duration of } \\
\ldots \text { migration }\end{array}$} & Less than 20 & 0.291 & 0.027 & 0.175 & 0.090 & 0.243 & 0.328 & 0.171 & 0.261 & 0.111 \\
\hline & $20-29$ & 0.230 & 0.083 & 0.134 & 0.233 & 0.409 & 0.440 & 0.490 & 0.546 & 0.214 \\
\hline & $30-39$ & 0.216 & 0.429 & 0.379 & 0.340 & 0.230 & 0.144 & 0.167 & 0.101 & 0.336 \\
\hline & At least 40 years & 0.214 & 0.398 & 0.204 & 0.223 & 0.047 & 0.056 & 0.052 & 0.074 & 0.258 \\
\hline \multicolumn{2}{|c|}{ Number of observations } & 444 & 2322 & 269 & 2095 & 379 & 125 & 251 & 326 & 6211 \\
\hline
\end{tabular}

Source: Survey PRI 2003. 
Table 2. Generalized Ordered Probit estimates of self-reported health among older migrants

\begin{tabular}{|c|c|c|c|c|c|c|c|}
\hline \multirow[t]{2}{*}{ Variables } & & \multicolumn{3}{|c|}{ Men } & \multicolumn{3}{|c|}{ Women } \\
\hline & & coef & & t-test & coef & & t-test \\
\hline \multicolumn{8}{|c|}{ Coefficients not varying by thresholds } \\
\hline Age & $50-54$ & $-0.127 * *$ & \multicolumn{2}{|c|}{-2.15} & -0.073 & \multicolumn{2}{|c|}{-1.23} \\
\hline \multirow{3}{*}{ (ref: 45-49) } & $55-59$ & $-0.262 * * *$ & \multicolumn{2}{|c|}{-4.04} & $-0.183 * * *$ & \multicolumn{2}{|c|}{-2.68} \\
\hline & $60-64$ & $-0.183 * *$ & \multicolumn{2}{|c|}{-2.51} & $-0.269 * * *$ & \multicolumn{2}{|c|}{-3.37} \\
\hline & 65 and more & $-0.192 * *$ & \multicolumn{2}{|c|}{-2.46} & $-0.359 * * *$ & \multicolumn{2}{|c|}{-4.18} \\
\hline \multicolumn{2}{|l|}{ In couple } & -0.021 & \multicolumn{2}{|c|}{-0.33} & -0.025 & \multicolumn{2}{|c|}{-0.48} \\
\hline \multirow{4}{*}{$\begin{array}{l}\text { Education } \\
\text { (ref: primary) }\end{array}$} & BEPC & 0.003 & \multicolumn{2}{|c|}{0.05} & $0.117 *$ & \multicolumn{2}{|c|}{1.74} \\
\hline & BEP-CAP & 0.041 & \multicolumn{2}{|c|}{0.61} & $0.302 * * *$ & \multicolumn{2}{|c|}{3.81} \\
\hline & Baccalaureate & 0.094 & \multicolumn{2}{|c|}{1.10} & $0.211 * *$ & \multicolumn{2}{|c|}{2.38} \\
\hline & High education & $0.209 * *$ & & 48 & $0.313^{* * *}$ & & 37 \\
\hline Occupation & Self-employed & -0.274 & & 91 & $0.249^{*}$ & & 89 \\
\hline (ref: inactive) & Executive & -0.314 & & 04 & $0.431 * * *$ & & 55 \\
\hline & Intermediary & -0.272 & & 91 & 0.079 & & 81 \\
\hline & Employee & -0.381 & & 27 & $0.146^{* *}$ & & 23 \\
\hline & Worker & $-0.533^{*}$ & & 80 & -0.004 & & \\
\hline Income & Quartile 2 & -0.017 & & 29 & 0.074 & & 24 \\
\hline & Quartile 3 & $0.141 * *$ & & 44 & $0.174 * * *$ & & 77 \\
\hline & Quartile 4 & $0.213^{* * *}$ & & 35 & $0.237 * * *$ & & 45 \\
\hline Liquidity constr & ined & $-0.173 * * *$ & & 20 & $-0.316^{* * *}$ & & \\
\hline Any IADL & & $-0.210 * * *$ & -15 & & $-0.246 * * *$ & -18 & \\
\hline Any stay in hos & ital & $-0.541 * * *$ & & 77 & $-0.509 * * *$ & & \\
\hline Father alive & & 0.017 & & 23 & $0.179 * *$ & & 56 \\
\hline Mother Alive & & $0.170 * * *$ & & 96 & $0.125 * *$ & & 05 \\
\hline Father in poor $h$ & alth & $-0.223 * * *$ & & 51 & $-0.197 * * *$ & & \\
\hline Mother in poor & ealth & $-0.178^{*}$ & & 88 & -0.095 & & \\
\hline Situation during & Poor & 0.029 & & 53 & 0.094 & & 43 \\
\hline$\ldots$ youth & Fair & 0.019 & & 36 & $0.166^{* * *}$ & & 73 \\
\hline (ref: very poor) & Good & $0.188 * * *$ & & 63 & $0.277 * * *$ & & 69 \\
\hline Duration of & $20-29$ & 0.010 & & 16 & -0.071 & & \\
\hline ... migration & $30-39$ & $-0.096^{*}$ & & 68 & -0.093 & & \\
\hline$($ ref: $<20)$ & At least 40 years & -0.032 & & 49 & 0.036 & & 50 \\
\hline Thresholds vary & & $\begin{array}{l}\text { From poor } \\
\text { to fair }\end{array}$ & $\begin{array}{l}\text { From fair to } \\
\text { good }\end{array}$ & $\begin{array}{l}\text { From good } \\
\text { to very good }\end{array}$ & $\begin{array}{l}\text { From poor } \\
\text { to fair }\end{array}$ & $\begin{array}{l}\text { From fair to } \\
\text { good }\end{array}$ & $\begin{array}{l}\text { From good } \\
\text { to very good }\end{array}$ \\
\hline Origin country & Southern Europe & -0.201 & $-0.523 * * *$ & $-0.385 * * *$ & $-0.304^{*}$ & $-0.474 * * *$ & $-0.372 * * *$ \\
\hline (ref : Northern & Eastern Europe & -0.194 & -0.266 & $-0.476^{* *}$ & $-0.419 * *$ & -0.177 & -0.215 \\
\hline ... Europe) & Northern Africa & -0.184 & $-0.524 * * *$ & $-0.227^{*}$ & -0.103 & $-0.622 * * *$ & $-0.353 * * *$ \\
\hline & Southern Africa & -0.059 & $-0.291 *$ & -0.108 & 0.152 & $-0.351 * *$ & $-0.531 * * *$ \\
\hline & America & 0.243 & -0.332 & 0.003 & -0.016 & $-0.365^{* *}$ & -0.108 \\
\hline & Middle & $-0.488^{* *}$ & $-0.591^{* * *}$ & -0.264 & 0.047 & $-0.571 * * *$ & -0.295 \\
\hline & Asia & -0.092 & $-0.508 * * *$ & $-0.281^{*}$ & -0.104 & $-0.495 * * *$ & -0.178 \\
\hline Difficulty in rea & ling French & 0.006 & $-0.177 * * *$ & -0.051 & 0.048 & $-0.250 * * *$ & -0.051 \\
\hline Number of obse & vations & & 3329 & & & 2882 & \\
\hline Log likelihood & & & -3717.8 & & & -3007.0 & \\
\hline
\end{tabular}

Source: Survey PRI 2003.

Note: significance levels are respectively $1 \%(* * *), 5 \%(* *)$ and $10 \%(*)$. The $t$-values associated to the coefficients explaining the threshold levels of the ordered model are not reported. 
Figure 1. Differences in self-reported health, by country

$$
\text { A. Men }
$$

$\square$ Very good $\square$ Good $\square$ Fair $\square$ Poor
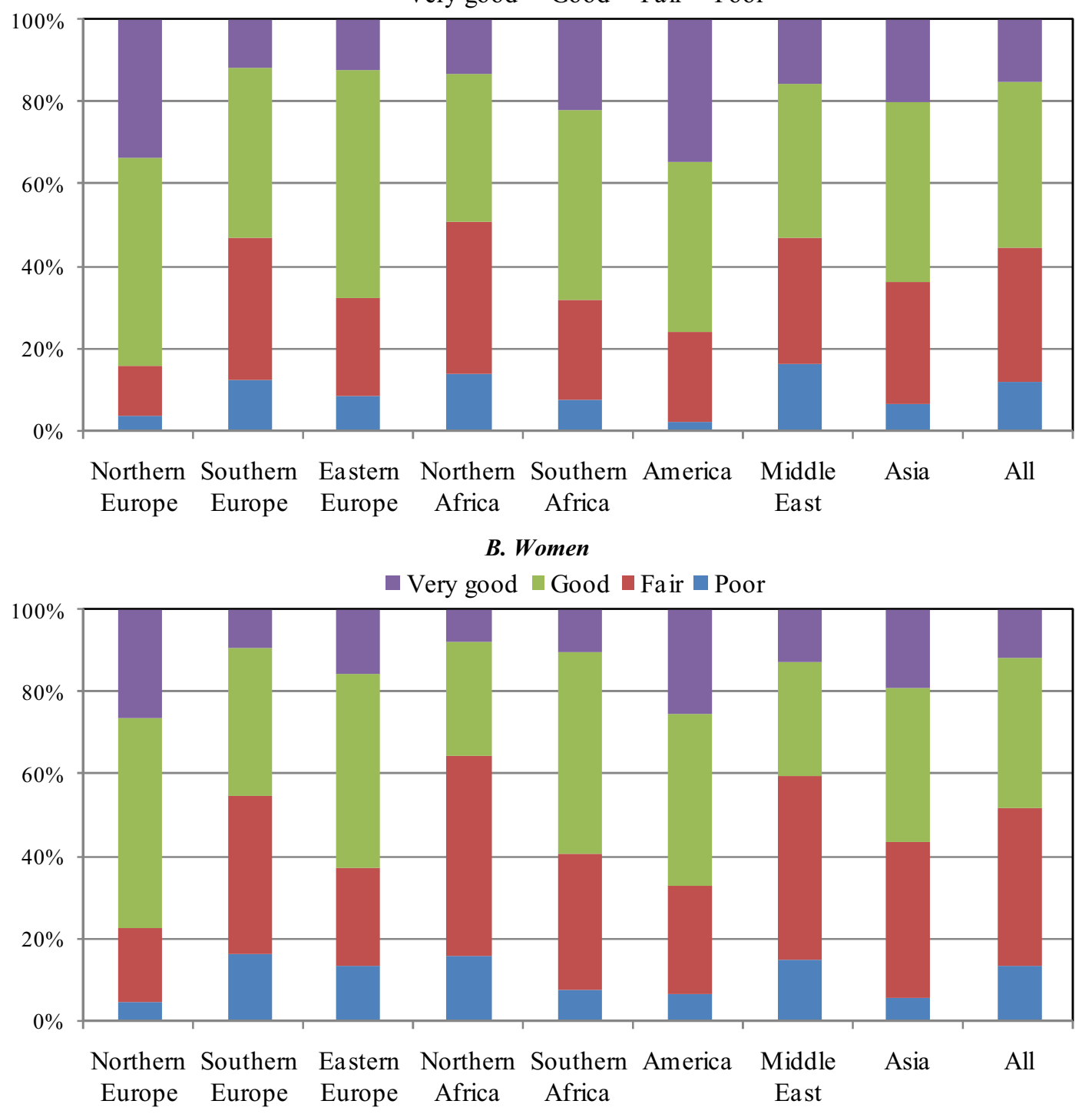

Source: Survey PRI 2003. 
Figure 2. Measures of the true health status, by origin country A. Men

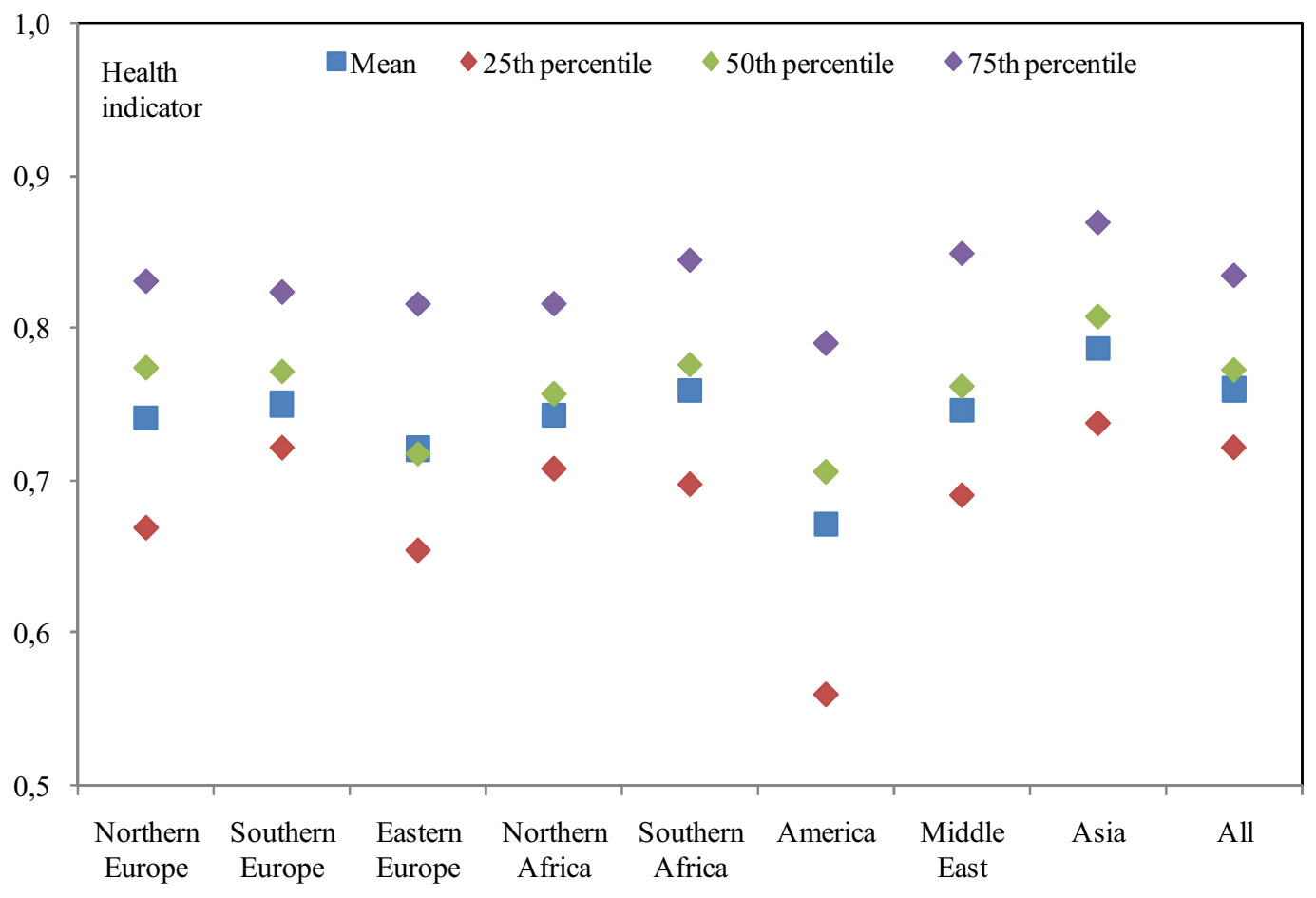

B. Women

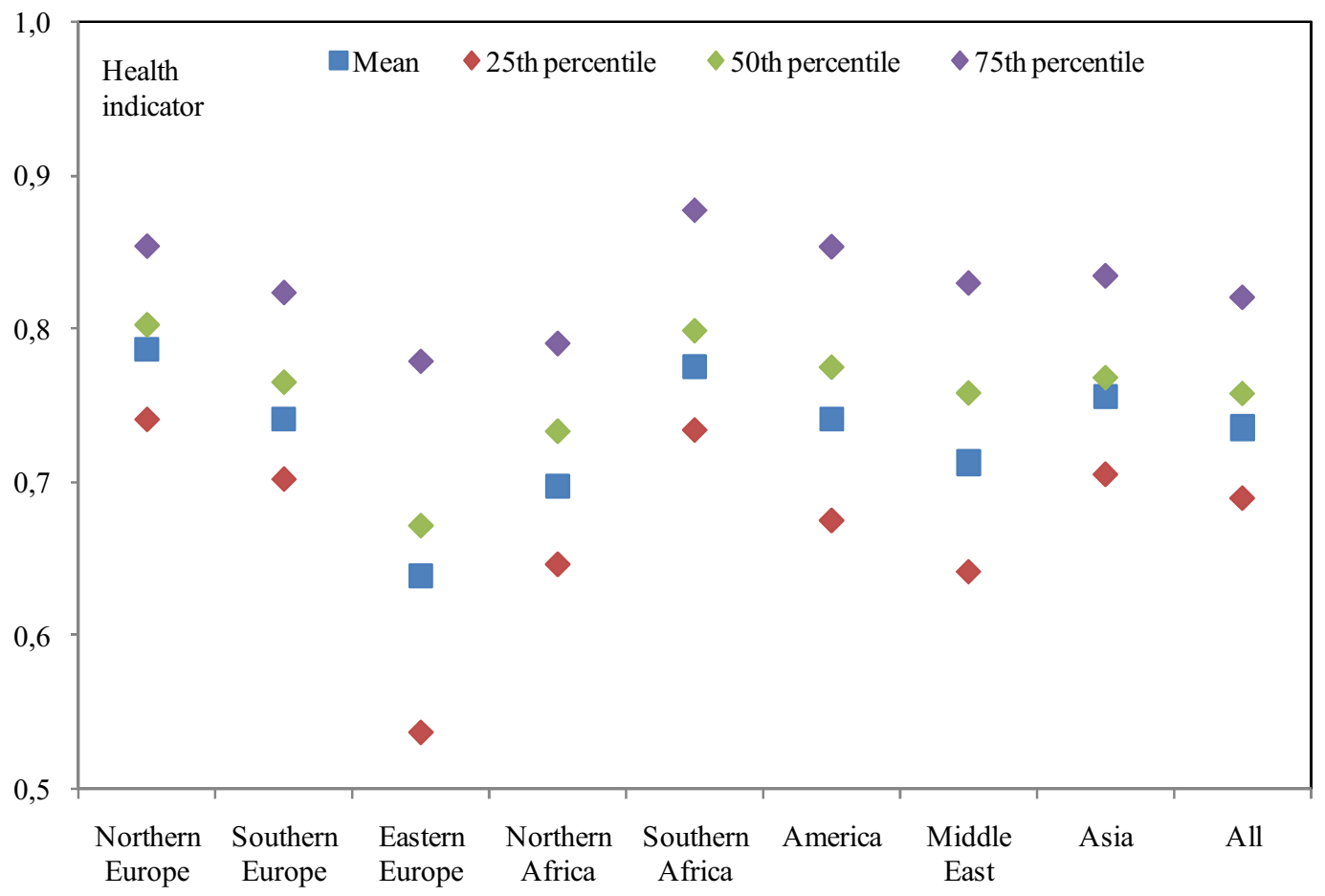

Source: Survey PRI 2003. 


\title{
References
}

\begin{abstract}
${ }^{1}$ Jasso G., Massey D.S., Rosenzweig M.R., Smith J.P., (2004), 'Immigrant health: Selectivity and acculturation', in Anderson N.B., Bulatao R.A., Cohen B., eds, Critical perspectives on racial and ethnic differences in health in late life, Washington, pp. 227-266.

${ }^{2}$ McDonald J.T., Kennedy S., (2004), 'Insights into the healthy immigrant effect: Health status and health service use of immigrants to Canada', Social Science and Medicine, vol. 59, pp. 1613-1627.
\end{abstract}

${ }^{3}$ Lu Y., (2008), 'Test of the healthy migrant hypothesis: A longitudinal analysis of health selectivity of internal migration in Indonesia', Social Science and Medicine, vol. 67, pp. 13311339.

4 Abraído-Lanza A.F., Dohrenwend B.P., Ng-Mak D.S., Turner J.B., (1999), 'The Latino mortality paradox: A test of the salmon bias and healthy migrant hypotheses', American Journal of Public Health, vol. 89, pp. 1543-1548.

5 Turra C.M., Elo I.T., (2008), 'The Impact of salmon bias on the Hispanic Mortality Advantage: New Evidence from Social Security Data', Population Research and Policy Review, vol. 27, pp. 515-530.

${ }^{6}$ Heron M.P., Schoeni R.F., Morales L., (2001), 'Health disparities among older immigrants in the United States', mimeo, Florida State University.

${ }^{7}$ Argeseanu Cunningham S., Ruben J.D., Narayan K.M.V., (2008), 'Health of foreign-born people in the United States: A review', Health and Place, vol. 14, pp. 623-635

${ }^{8}$ Uniken Venema H.P., Garretsen H.F.L., Van der Maas P.J., (1995), 'Health of migrants and migrant health policy, the Netherlands as an example', Social Science and Medicine, vol. 41, pp. 809-818.

${ }^{9}$ Pudaric S., Sundquist J., Johansson S.-E., (2003), 'Country of birth, instrumental activities of daily living, self-rated health and mortality: A Swedish population-based survey of people aged 55-74', Social Science and Medicine, vol. 56, pp. 2493-2503.

${ }^{10}$ Lert F., Melchior M., Ville I., (2007), 'Functional limitations and overweight among migrants in the Histoire de Vie study', Revue d'Epidemiologie et de Santé Publique, vol. 55, pp. 391-400.

11 Attias-Donfut C., Tessier P., (2005), 'Santé et vieillissement des immigrés', Retraite et Société, ${ }^{\circ}$ 46, pp. 90-129.

${ }^{12}$ Jusot F., Solva J., Dourgnon P., Sermet C., (2009), 'Inégalités de santé liées à l'immigration 
en France. Effet des conditions de vie ou sélection à la migration ?', Revue Economique, vol. 60 , pp. $385-411$.

${ }^{13}$ Darmon N., Khlat M., (2001), 'An overview of the health status of migrants in France in relation to their dietary practices', Public Health, vol. 4, pp. 163-172.

${ }^{14}$ Mejean C., Traissac P., Eymard-Duvernay S., El Ati J., Delpeuch F., Maire B., (2007), 'Diet quality of North African migrants in France partly explains their lower prevalence of diet-related chronic conditions relative to their native French peers', Journal of Nutrition, vol. 137, pp. $2106-2113$.

${ }^{15}$ Méjean C., Traissac P., Eymard-Duvernay S., Delpeuch F., Maire B., (2009), 'Influence of acculturation among Tunisian migrants in France and their past/present exposure to the home country on diet and physical activity', Public Health Nutrition, vol. 12, pp. 832-841.

${ }^{16}$ Bouchardy C., Parkin D.M., Wanner P., Khlat M., (1996), 'Cancer mortality among North African migrants in France', International Journal of Epidemiology, vol. 25, pp. 5-13.

${ }^{17}$ Rafnsson S.B., Bhopal R.S., (2008), 'Migrant and ethnic health research: Report on the European Public Health Association Conference', Public Health, vol. 122, pp.532-534.

${ }^{18}$ Idler E.L., Benyamini, (1997), 'Self-rated health and mortality: A review of twenty-seven community studies', Journal of Health and Social Behavior, vol. 38, pp. 21-37.

${ }^{19}$ Attias-Donfut C., Davaut P., Gallou R., Rozenkier A., Wolff F.C., (2006), L'enracinement. Enquête sur le vieillissement des immigrés en France, Armand Colin, Paris.

${ }^{20}$ Jürges H., (2007), 'True health versus response styles: Exploring cross-country differences in self-reported health', Health Economics, vol. 16, pp. 163-178.

${ }^{21}$ King G., Murray C.J.L., Salomon J.A., Tandon A., (2004), 'Enhancing the validity and cross-cultural comparability of measurement in survey research', American Political Science Review, vol. 98, pp. 191-207.

${ }^{22}$ Williams R., (2006), 'Generalized ordered Logit/Partial proportional odds model for ordinal dependent variables', Stata Journal, vol. 6, pp. 58-82.

${ }^{23}$ Dwyer D.S., Mitchell O.S., (1999), 'Health problems as determinants of retirement: Are self-rated measures endogenous?', Journal of Health Economics, vol. 18, pp. 173-193.

${ }^{24}$ Kandula N.R., Laudedale D.S., Baker D.W., (2007), 'Differences in self-reported health among Asians, Latinos, and non-Hispanic Whites: The role of language and nativity', Annals of Epidemiology, vol. 17, pp. 191-198. 